\title{
Teacher Advocacy in the time of COVID-19: Rethinking Teacher Education Curriculums
}

\author{
Karlin Burks, Nicole Austin, Kimberly Fitchett-Bazemore \\ Elizabeth City State University, USA
}

\begin{abstract}
As COVID-19 ravages our country and devastates our K12 Education system, the crisis has highlighted the need for teachers to be educated in the art of advocacy as a necessary skill for reforming the teaching profession (Brown, 2008). Despite the necessity of teachers to possess practical advocacy skills to advocate for themselves and their students, many teacher preparation programs do not provide courses that incorporate teacher advocacy. This article serves to provide a 3-step plan in which institutions can use to revamp their current undergraduate education curriculums to include advocacy instruction for their preservice teachers.
\end{abstract}

Keywords: Teacher advocacy, advocacy, teacher preparation programs

\section{Introduction}

Never before has teacher advocacy been at the forefront of teacher education than it is right now in the time of COVID-19. Teachers, once relegated to the sidelines of educational policy and decision making, have been forced out of the shadows to advocate for the rights and 
safety of themselves, their colleagues, and their students (Flannery, 2020; Force, 2020). But, as teachers venture down this new path, are they prepared and trained to take on these new challenges?

Should teachers be forced to return to in-person instruction is the heart of the COVID-19 fight, as remote learning has become the safer alternative to the unprecedented school closures occurring worldwide (UNESCO Educational Sector, 2020). Parents want teachers back in the classroom, sentiments echoed by politicians, including President of the United States, Donald Trump. But are lawmakers and parents basing their decisions on teacher safety or personal convenience? Moreover, as parents have to step into the new role of teacher, finally realizing that the art of teaching is far more challenging and complex than they previously credited to the profession?

The idea that teachers are true professionals and good at their jobs is finally being acknowledged and valued by society. Teachers around the globe have seamlessly adapted their instruction and engagement of students from the classroom to virtual spaces, responding to the sudden need to be physically separated from their students (Trombly, 2020). While it is regrettable that it has taken a pandemic for teachers to be afforded the respect due to the profession, now is the time to push forward and capitalize on the opportunity to impact education policy through teacher advocacy (Trombly, 2020).

\section{Teacher Advocacy Standard}

In Educator Preparation Programs (EPP's) across the nation, teaching standards are the foundation for which most programs are built. In North Carolina, professional teaching standards serve as the basis for teacher preparation in all Higher Education institutions. North Carolina's Professional Teaching Standards include five primary strands that govern teacher education practice throughout the state. Standard one focuses on teacher advocacy, specifically charging teachers with advocating for positive changes in policies and practices affecting student learning (North Carolina Professional Teaching Standards, 2013). Teacher education faculty use these standards to develop and refine preservice teacher curriculums for their students. However, many, if not most, institutions do not explicitly devote any substantial training to the area of teacher advocacy. So, how are preservice teachers to accomplish the goal of advocating for the profession if they were never introduced nor trained in the fine arts of teacher advocacy? 
Another critical point to consider around teacher advocacy is how the teacher advocacy standard is measured in Educator Preparation Programs. Although teacher advocacy is the first standard in North Carolina's Professional Teaching Standards, there is no concrete language outlining how programs should measure teacher advocacy or how teacher candidates can demonstrate mastery in this area. In North Carolina, evaluating teacher advocacy mastery rests solely with the individual institution, which is problematic because not every university views teacher advocacy as an essential teacher skill.

\section{Higher Education Connection}

Historically, EPPs have sought to train teachers by providing them with a robust theoretical base, followed by opportunities to practice what they have learned in the field in the form of field experience and clinical practice. Instructing preservice teachers in the art of advocacy was never a curriculum priority. Although teacher education programs vary by the institution in North Carolina, there is no state-mandated advocacy curriculum, nor is there any instruction on precisely what teacher advocacy is or how students can engage in advocacy concepts or processes (Hollingsworth et al., 2016). Simply put, EPP's have dropped the ball in the area of teacher advocacy.

Recently, educators have issued advocacy calls to action to ensure that teachers' rights are recognized and protected during COVID-19, emphasizing that nothing is more important than student and educator safety (Flannery, M.E. 2020; Force, 2020). The COVID-19 crisis has further highlighted the need for teachers to be educated in advocacy, outlining it as an essential tool used in reforming the teaching profession (Brown, 2008). Additionally, researchers have noted that Educator Preparation Programs should explicitly develop programs and activities to engage preservice teachers in advocacy initiatives (Brown, 2008; Dever, 2006). Researchers also agree that EPP's should take a role in providing future teachers with the knowledge and skills needed to engage in advocacy efforts to influence education policies (Hollingsworth et al., 2016).

Traditionally, teacher advocacy has not been an emphasized part of teacher education curriculums. However, 2020 has highlighted the need for teachers to be well-versed in this skill. According to Brown (2008), preservice teachers need to be introduced to the idea of teacher advocacy gradually, starting in small chunks. By gradually providing advocacy opportunities and activities, preservice teachers can slowly build their skillset, stretching 
across their entire preparation program. Thus, Educator Preparation Programs should examine their current curriculum specific to teacher advocacy and make changes to enhance their teacher's skillset across their programs.

\section{Examination of the Curriculum and Key Word Analysis}

As we sought to examine teacher advocacy instruction at our EPP, our first step was to identify whether teacher advocacy was currently being offered within our education courses. We decided to audit our education classes, restricting our examination to the elementary education curriculum. We chose to focus on the undergraduate elementary education program as it serves $51 \%$ of the total students enrolled in the School of Education.

Most Elementary Education programs around the nation, prepare their preservice teachers to teach a variety of elementary subjects such as reading, social studies, science, and mathematics. As a result, elementary curriculums are typically heavy with courses dedicated to the methods of teaching those subject areas and the pedagogy of teaching. At our EPP, we offer five core elementary education courses, eleven additional education courses that further support the program and student learning.

For the course audit, we analyzed syllabi in the undergraduate elementary education program for specific activities or learning outcomes that could be linked or related to teacher advocacy. As all program syllabi include course descriptions of pedagogy and details regarding signature assignments, we expected to ascertain whether advocacy was a topic covered in any of those courses. Additionally, to ensure that we were examining courses taken by most elementary education students, we further restricted our study to the ten classes required for formal admission into the teacher education program.

The ten syllabi were scrutinized and carefully examined for any connection to teacher advocacy. The keywords we identified for our target search were advocacy, community, collaboration, and writing. We chose the keywords community and collaboration because research asserts that advocacy cannot be conducted in a vacuum; it must occur through collaborating with the community (Trombly, 2020). Finally, the writing keyword was added to identify courses with formal writing assignments that could be used in conjunction with future teacher advocacy activities. The results of the ten-course syllabi analysis examined are outlined in Table 1. 
Table 1 Examination of Course Syllabi for Admitted Elementary Education Students

\begin{tabular}{|c|c|c|c|c|}
\hline \multirow{2}{*}{$\begin{array}{l}\text { Courses for } \quad \text { Admitted } \\
\text { Elementary Education Students }\end{array}$} & \multicolumn{4}{|c|}{ Key Terms found in Course Syllabi } \\
\hline & Community & Advocacy & Collaboration & Writing \\
\hline $\begin{array}{l}\text { ELEM 300: } \\
\text { Reading \& Language Arts }\end{array}$ & $\mathbf{X}$ & & $\mathbf{X}$ & $\mathbf{X}$ \\
\hline $\begin{array}{l}\text { ELEM 390: } \\
\text { Social Studies in the Inclusive } \\
\text { Classroom }\end{array}$ & & & $\mathbf{X}$ & $\mathbf{X}$ \\
\hline $\begin{array}{l}\text { ELEM 395: } \\
\text { Science Methods in the } \\
\text { Inclusive Classroom }\end{array}$ & & & $\mathbf{X}$ & $\mathbf{X}$ \\
\hline $\begin{array}{l}\text { ELEM 410: } \\
\text { Instructional Methods and } \\
\text { Leadership }\end{array}$ & & & & \\
\hline $\begin{array}{l}\text { ELEM 430: } \\
\text { Mathematics Methods in the } \\
\text { Inclusive Classroom }\end{array}$ & & & & \\
\hline $\begin{array}{l}\text { EDUC 350: } \\
\text { Intermediate and Content } \\
\text { Reading }\end{array}$ & & & $\mathbf{X}$ & $\mathbf{X}$ \\
\hline $\begin{array}{l}\text { EDUC 360: } \\
\text { Teaching and Assessment }\end{array}$ & & & $\mathbf{X}$ & \\
\hline $\begin{array}{l}\text { EDUC 479: } \\
\text { Multicultural Education }\end{array}$ & $\mathbf{X}$ & & & \\
\hline $\begin{array}{l}\text { EDUC 433: } \\
\text { Clinical Practice }\end{array}$ & $\mathbf{X}$ & & $\mathbf{X}$ & \\
\hline
\end{tabular}




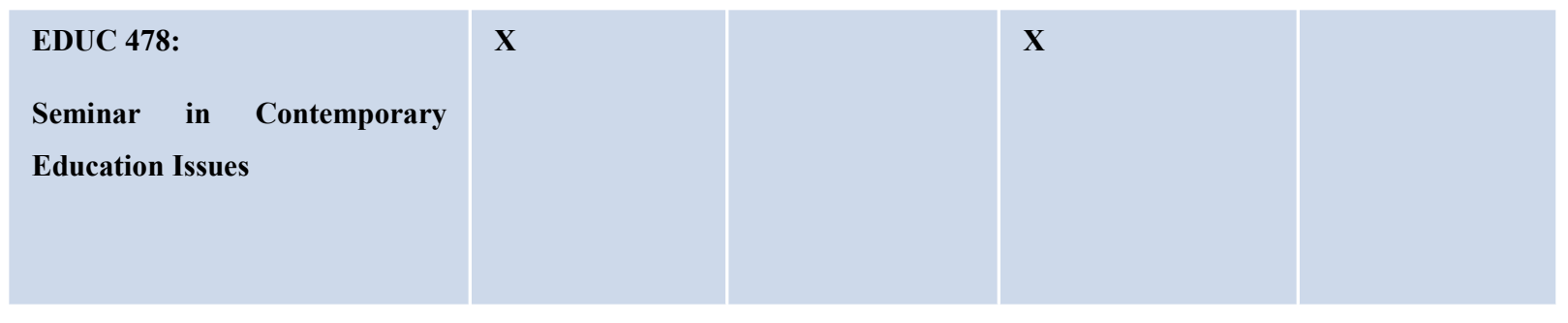

\section{Data Reflection}

After extensive examination of the Elementary Education program's ten required courses, we discovered a significant omission in teacher advocacy instruction at our institution. Sadly, none of the ten classes required for formal admission into the teacher education program included any advocacy instruction or student advocacy assignments. As standard one of The North Carolina Professional Teaching Standards (2013) included the need for teachers to advocate for positive change in policies and practices affecting student learning, we considered this a significant oversight in our teacher education program.

Although we found the study's keywords sprinkled throughout many of the elementary education syllabi, the total number of courses containing formal assignments was not significant. The topic of collaboration was the most widely covered across the program, with seven out of ten $(70 \%)$ courses requiring either a collaborative activity or signature assignment centered on collaboration. The community topic was found in only four out of the ten $(40 \%)$ required classes, with activities or signature assignments focused on students attending community themed events. Finally, and most surprising, only four out of the ten (40\%) undergraduate Elementary Education program courses required any formal writing assignment.

\section{Curricular Recommendations}

Acknowledging the lack of teacher advocacy instruction available at our institution, we decided to recommend to the school of education faculty, instructional changes to the ten courses highlighted in this study. Although the data would support developing a new course to support the teacher advocacy standard, adding to an already packed degree program is not an option. Thus, as higher education faculty, we need to find creative ways to include noncore topics in our existing courses if we are to cover all required teacher standards. 
Advocacy is one such non-core topic we believe should be addressed early in the teacher education curriculum. Teaching preservice teachers what teacher advocacy is and how to advocate for the profession is pivotal to all future teachers but can also be pivotal to the health and wellbeing of all the children they serve (Dever, 2006). Further, to support the development of advocacy skills in preservice teachers, we concur with current research on this issue that the curriculum should address the development of teacher skills, such as the ability (a) to assess advocacy issues, (b) to utilize communication skills, and (c) to identify resources (Liebovich \& Adler, 2009). The following proposed curricular recommendations are derived from teacher advocacy best practices and our professorial experience working with preservice teachers.

\section{A Proposed Advocacy Integrated 3-Step Plan}

Typically, all Educator Preparation Programs include at least one introductory course in their teacher education curriculum. We propose introducing the topic of teacher advocacy in the introductory course. Our first step would be to develop an introductory video detailing the significance of teacher advocacy and how preservice teachers can adequately identify and assess advocacy opportunities. The course's goal would be to familiarize preservice teachers with teacher advocacy and instruct them on how to identify advocacy opportunities in their school or community.

The second step would focus on improving preservice teacher's writing skills and providing more opportunities for formal writing assignments in our program. Teacher advocacy writing assignments can provide more formal writing opportunities for our preservice teachers and support teacher advocacy instruction. Assignments, where students design and implement authentic advocacy projects, can easily be implemented into the program curriculum (Dever, 2006). Examples of advocacy writing assignments include writing advocacy letters to local, state, or national politicians on a current issue affecting educational reform or writing opinion pieces to their local newspaper or online blog about issues affecting student learning.

The final step would provide teachers with a refresher course on their teacher advocacy instruction and be offered before the student teaching semester. The inclusion of a required advocacy module as a prerequisite to student teaching would be an excellent way to ensure broad exposure to the topic of teacher advocacy before students leave the program. Faculty 
could design modules to provide a comprehensive review of the teacher advocacy issue and provide tangible next steps for teachers to try out on the field.

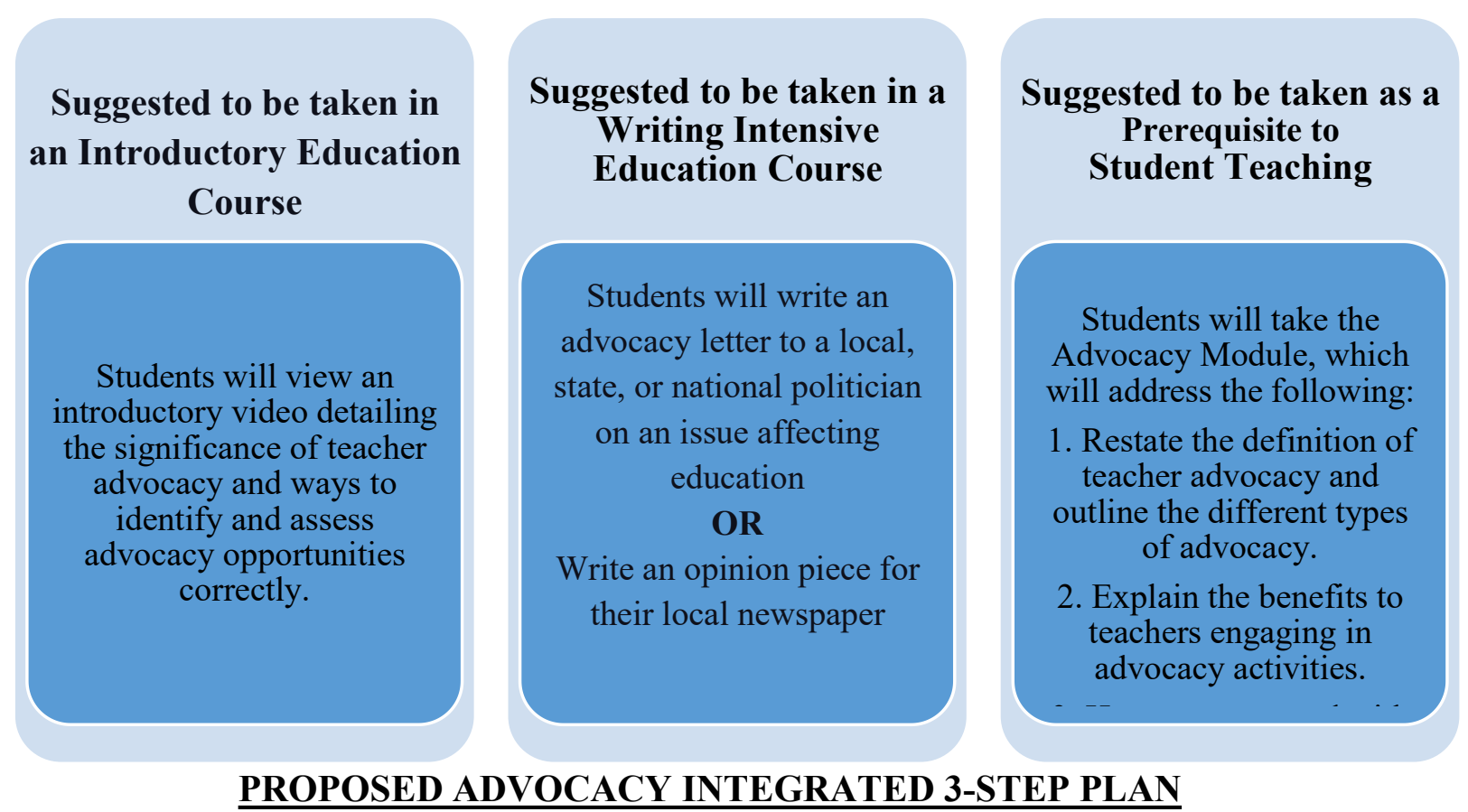

Figure 1: Illustrates a Proposed Advocacy Integration 3-step Plan

\section{Conclusion}

If COVID-19 has taught educators anything, it is that teachers need to understand the power of advocacy and should be trained in the art of teacher advocacy. Issues around COVID-19 health and safety are two immediate areas impacting educators in which they need to become more vocal advocates in expressing their views and defending their rights. Advocacy training is also essential for reforming the teaching profession (Brown, 2008), particularly as additional demands placed on teachers, is having a detrimental effect on their mental health and overall well-being.

In order to support the development of advocacy skills in preservice teachers, teacher education curriculums must address the gaps in advocacy instruction at their institutions (Liebovich \& Adler, 2009). While the task of integrating teacher advocacy into current curriculums might seem arduous or even tedious, the teaching field can be strengthened by having teachers who are competent Advocators (Liebovich \& Adler, 2009). Having twentyfirst century teachers ready and willing to "advocate for positive changes in policies and 
practices" (North Carolina Professional Teaching Standards, 2013) would benefit the teaching profession and serve as a catalyst to change the landscape of teacher education around the Nation.

\section{References}

[1] Brown, C. P. (2008). Research in review: Advocating for policies to improve practice. Young Children, 63(4), 70-77.

[2] Dever, D. (2006). Early childhood teacher education policy: Linking teacher educators and policy makers. Journal of Early Childhood Teacher Education, 27, 391-399.

[3] Flannery, M.E. (2020, March 26). During Pandemic, Unions Continue to Advocate for Educators and Students. National Education Association. https://www.nea.org/advocating-for-change/new-from-nea/during-pandemic-unionscontinue-advocacy

[4] Force, T. (2020). Teacher Task Force calls to support 63 million teachers touched by the COVID-19 crisis. Retrieved October 09, 2020, from https://teachertaskforce.org/news/teacher-task-force-calls-support-63-million-teacherstouched-covid-19-crisis

[5] Hollingsworth, H., Knight-McKenna, M., \& Bryan , R. (2016) Policy and advocacy concepts and processes: innovative content in early childhood teacher education, Early Child Development and Care, 186:10, 1664-1674. http://doi.org/10.1080/03004430.2015.1121252

[6] Liebovich, B.J. and Adler, S.M. (2009a). Teaching Advocacy in Early Years Initial Teacher Education Programmes. Forum, 51(1), 25-34. http://doi.org/10.2304/forum.2009.51.1.25

[7] North Carolina Department of Public Instruction. (2013). North Carolina Professional Teaching Standards. https://files.nc.gov/dpi/north_carolina_professional_teaching_standards_2.pdf

[8] Trombly, C.E. (2020), "Learning in the time of COVID-19: capitalizing on the opportunity presented by the pandemic", Journal of Professional Capital and Community, Vol. ahead-of-print No. ahead-of-print. https://doi.org/10.1108/JPCC-05-2020-0016 
[9] UNESCO Educational Sector. 2020, April. "Distance Learning Strategies in Response to COVID-19 School Closures." UNESCO COVID-19 Education Response, Education Sector Issue Note n 2.1. 